\title{
Adjuvant Chemotherapy in Elderly Patients with Early-stage Non-small Cell Lung Cancer
}

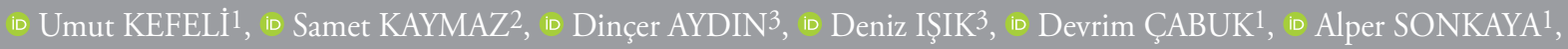 \\ (i) Özgür AÇIKGÖZ1, id Ulaş IŞIK1, id Ercan ÖZDEN1, ib Kazım UYGUN1 \\ ${ }^{1}$ Kocaeli University Faculty of Medicine, Department of Medical Oncology, Kocaeli, Turkey \\ 2Kocaeli University Faculty of Medicine, Department of Internal Medicine, Kocaeli, Turkey \\ ${ }^{3}$ Dr. Lütfi Kurdar Kartal Training and Research Hospital, Clinic of Medical Oncolgy, İstanbul, Turkey
}

\begin{abstract}
Objective: Early-stage non-small cell lung cancer (NSCLC) constitutes approximately 25-30\% of newly diagnosed lung cancers. Elderly patients with NSCLC have generallly been underrepresented in clinical studies. We explored adjuvant chemotherapy results in patients $\geq 65$ years with early-stage NSCLC.

Methods: The medical records of 111 elderly patients with early-stage NSCLC were reviewed retrospectively. Collected data included demographic information, clinical assessments and information on treatment. Survival was estimated using the Kaplan-Meier method and prognostic factors were evaluated with log-rank and Cox regression tests.

Results: The median disease-free survival (DFS) was 22.6 months. In univariate analysis, significant association between stage, performance score (PS), adjuvant chemotherapy and DFS was detected ( $\mathrm{p}<0.05)$. Stage, PS and adjuvant chemotherapy were found to have significant effects on overall survival (OS) $(\mathrm{p}<0.05)$. The median survival for the entire group was 41.6 months. Multivariate analysis showed that stage, PS and adjuvant chemotherapy affected both DFS and OS.

Conclusion: Survival of elderly patients with early-stage NSCLC was significantly influenced by stage, PS and adjuvant chemotherapy. These factors, rather than age, should be considered in the treatment planning for elderly patients with NSCLC.
\end{abstract}

Keywords: Adjuvant, elderly, non-small cell lung cancer

\section{Introduction}

Non-small cell lung cancer (NSCLC) remains the leading cause of cancer-related deaths in the US. A total of 224.390 new lung cancer cases and 158.080 deaths from lung cancer were expected to occur in the United States in 2016 (1). In Turkey, lung cancer is the leading cause of cancer in men in all age groups and in male patients older than 50 years. It is the fourth common cause of all cancers in women in all age groups and third common cause in female patients older than 50 years (2). Approximately $85 \%$ of all lung cancers are non-small cell, and majority of these cases are metastatic or advanced at diagnosis (3).

Between 2010 and 2030, a 67\% increase in cancer incidence is anticipated for patients aged $\geq 65$ years (4). Specifically, half of the newly diagnosed NSCLC cases occur in patients aged $\geq 65$ years (5). Additionally, elderly patients suffer from approximately twice as many comorbidities compared with the general population which may have a considerable impact on their health and performance status (6).

Address for Correspondence: Umut KEFELi, Kocaeli University Faculty of Medicine, Department of Medical Oncology, Kocaeli, Turkey

E-mail: ukefeli@yahoo.com ORCID ID: orcid.org/0000-0001-6126-5377

Cite this article as: Kefeli U, Kaymaz S, Aydın D, Işık D, Çabuk D, Sonkaya A, Açıkgöz O, Işık U, Ozden E, Uygun K. Adjuvant Chemotherapy in Elderly Patients with Early-stage Non-small Cell Lung Cancer. Bezmialem Science 2019;7(4):265-70. 
In clinical trials, the definition of an elderly patient remains controversial. Epidemiologic literature uses an age of 65 years for the selection of elderly patients (7). It should be noted, however, that there is little knowledge regarding the management of resected elderly patients with NSCLC (8). Therefore, in this study we evaluated the patients $\geq 65$ years of age with surgically resected early-stage NSCLC who had also received adjuvant chemotherapy.

\section{Methods}

We retrospectively analyzed the records of the 111 patients who were aged $\geq 65$ years with NSCLC from December 2005 to January 2015 at the Dr. Lütfi Kırdar Kartal Training and Research Hospital and Kocaeli University School of Medicine. Ethics committee approval was obtained from the local committee. Written informed consent was not obtained from patients due to the retrospective nature of the study. All medical records were collected through a detailed review of the patients'charts. The data included demographics, histology, staging, presenting symptoms, treatments, toxicities, and treatment side-effects. TNM classification ( $7^{\text {th }}$ edition) was used for staging of the patients. Eastern Cooperative Oncology Group (ECOG) performance score (PS) was used for the detection of performance status (9).

These 111 patients that underwent surgery (all of the patients) had no significant comorbidities. Of these, patients who did not receive chemotherapy had stage $1 \mathrm{~A}$ disease and $1 \mathrm{~B}$ disease with good prognostic criteria. Eight patients were not given chemotherapy because of having a poor PS after surgery. Nineteen patiens with a good PS had stage 1B disease with poor risk factors and stage 2 disease did not receive chemotherapy. Therefore, out of 111 patients, 84 patients received chemotherapy and these 84 patients were compared with these 19 patients who were offered but did not receive chemotherapy. The response to therapy was determined according to the Response Evaluation Criteria in Solid Tumors criteria (10).

\section{Statistical Analysis}

SPSS 17.0 (SPSS Inc., Chicago, IL, USA) software was used for all statistical analyses. A $p$ value $\leq 0.05$ was considered to be significant. Toxicity was classified according to the World Health Organization criteria at each cycle of chemotherapy (11). KaplanMeier curves were used for the disease-free survival (DFS) and overall survival (OS) analysis and the log-rank test was used for comparisons. A Cox proportional hazard analysis was conducted in order to calculate hazard ratios [95\% confidence interval (CI)]. DFS was calculated from the diagnosis of the patient to the date of disease progression, recurrence or death from any cause. OS was calculated from the diagnosis of patient to the date of death from any cause or to the date of the last follow-up.

\section{Results}

Data from 111 patients aged $\geq 65$ years old were collected. Ninety-three patients (83.8\%) were male and 18 (16.2\%) were female. The median age of the patients was 68.0 years (range=65-82 years). Patients had no significant comorbidities. Thirty-eight patients (34.2\%) had hypertension, 6 patients had thyroid disorders $(5.4 \%), 5$ had renal disease $(4.5 \%)$ that were easily managable. In the histopathological examinations, 61 $(54.9 \%)$ of tumors (patients) were detected as squamous cell carcinoma and 33 (29.7\%) were adenocarcinoma. Eighty-one percent of the patients were managed with lobectomy, and 19\% with segmentectomy or wedge resection. Forty-five percent of the patients had clinical stage 1 and $55 \%$ had stage 2 disease. A PS score of $0-1$ and $2-4$ were recorded in $74.7 \%$ and $9.0 \%$ of the patients, respectively. Two-thirds of the patients had a smoking history. Approximately, one-third of the patients (32.4\%) experienced a weight loss of $\geq 5 \%$ in the last 3 months.

Patients who did not receive chemotherapy, had stage 1A disease and $1 \mathrm{~B}$ disease with good prognostic criteria and patients with poor PS after surgery did not receive chemotherapy. Therefore, 84 of 111 elderly patients with NSCLC who were eligible for chemotherapy received it. Nineteen patients with poor risk stage 1B disease and stage 2 disease did not receive chemotherapy (Table 1). There were no differences between the characteristics of the patients ( $p>0.05)$ (Table 1). Only 9 patients (10.7\%) with a PS of 2 received single-agent chemotherapy and 75

Table 1. Characteristics of the patients

\begin{tabular}{|c|c|c|c|}
\hline Characteristic & $\begin{array}{l}\text { Patients } \\
(n=84)^{*}\end{array}$ & \multicolumn{2}{|c|}{ Patients $(n=19) \pm$} \\
\hline \multicolumn{4}{|l|}{ Sex } \\
\hline $\begin{array}{l}\text { Male } \\
\text { Female }\end{array}$ & $\begin{array}{l}67(65.0 \%) \\
17(16.5 \%)\end{array}$ & $\begin{array}{l}12(11.7 \%) \\
7(6.8 \%)\end{array}$ & $p>0.05$ \\
\hline \multicolumn{4}{|l|}{ Age } \\
\hline Median (range) & $67.6(65-80)$ & $68(67-82)$ & $p>0.05$ \\
\hline \multicolumn{4}{|l|}{ ECOG PS } \\
\hline $\begin{array}{l}0-1 \\
2-4\end{array}$ & $\begin{array}{l}75(72.8 \%) \\
9(8.7 \%)\end{array}$ & $\begin{array}{l}14(13.5 \%) \\
5(5.0 \%)\end{array}$ & $p>0.05$ \\
\hline \multicolumn{4}{|l|}{ Weight loss } \\
\hline $\begin{array}{l}\geq 5 \% \text { in previous } 3 \\
\text { months } \\
\leq 5 \% \text { in previous } 3 \\
\text { months }\end{array}$ & $\begin{array}{l}24(23.3 \%) \\
60(58.2 \%)\end{array}$ & $\begin{array}{l}5(5.0 \%) \\
14(13.5 \%)\end{array}$ & $p>0.05$ \\
\hline \multicolumn{4}{|l|}{ Smoking habitus } \\
\hline $\begin{array}{l}\text { Current or former } \\
\text { Never }\end{array}$ & $\begin{array}{l}63(61.1 \%) \\
21(20.3 \%)\end{array}$ & $\begin{array}{l}12(12.0 \%) \\
7(6.6 \%)\end{array}$ & $p>0.05$ \\
\hline \multicolumn{4}{|l|}{ Histology } \\
\hline $\begin{array}{l}\text { Squamous cell } \\
\text { Adenocarcinoma } \\
\text { Others }\end{array}$ & $\begin{array}{l}52(50.4 \%) \\
20(19.4 \%) \\
12(11.7 \%)\end{array}$ & $\begin{array}{l}12(11.7 \%) \\
6(5.8 \%) \\
1(1.0 \%)\end{array}$ & $p>0.05$ \\
\hline \multicolumn{4}{|l|}{ Stage } \\
\hline $\begin{array}{l}1 \\
2\end{array}$ & $\begin{array}{l}38(36.8 \%) \\
46(44.6 \%)\end{array}$ & $\begin{array}{l}8(7.8 \%) \\
11(10.8 \%)\end{array}$ & $p>0.05$ \\
\hline \multicolumn{4}{|c|}{$\begin{array}{l}\text { *Patients that received chemotherapy, } \pm \text { Patients that did not receive } \\
\text { chemotherapy, ECOG PS: Eastern Cooperative Oncology Group Performance } \\
\text { Status }\end{array}$} \\
\hline
\end{tabular}


patients $(89.3 \%)$ received combination chemotherapy. Overall, carboplatin-based combinations (51.1\%) were most commonly administered. Thirty-six of these 84 patients (42.9\%) were treated with carboplatin-paclitaxel, 26 were treated with cisplatinvinorelbine $(31.0 \%)$, 4 were treated with carboplatin-vinorelbine (4.7\%), 6 were treated with cisplatin-docetaxel (7.1\%), 3 were treated with cisplatin-gemcitabine $(3.6 \%), 3$ were treated with single-agent docetaxel $(3.6 \%)$ and 6 were treated with singleagent gemcitabine $(7.1 \%)$. There were no differences between combination arms regarding to DFS or OS ( $>>0.05)$. Seventytwo patients (85.7) that received chemotherapy had $\geq 3$ cycles of chemotherapy. The most frequent toxicities were hematological

Table 2. Chemotherapy modalities and toxicities of the patients

\section{Patients}

$$
(n=84)
$$

\begin{tabular}{|l|l|l|}
\hline Chemotherapy regimen & & $(89.3 \%)$ \\
\hline $\begin{array}{l}\text { Combination } \\
\text { Single agent }\end{array}$ & 75 & $(10.7 \%)$ \\
\hline Combination therapy & 9 & $(42.9 \%)$ \\
\hline $\begin{array}{l}\text { Carboplatin-paclitaxel } \\
\text { Carboplatin-vinorelbine }\end{array}$ & 36 & $(4.7 \%)$ \\
\hline Cisplatin-docetaxel & 6 & $(7.1 \%)$ \\
\hline Cisplatin-gemcitabine & 3 & $(3.6 \%)$ \\
\hline Cisplatin-vinorelbine & 26 & $(31.0 \%)$ \\
\hline Docetaxel & 3 & $(3.6 \%)$ \\
\hline Gemcitabine & 6 & $(7.1 \%)$ \\
\hline Chemotherapy cycles & & \\
\hline$<3$ & 12 & $(14.3 \%)$ \\
\hline$\geq 3$ & 72 & $(85.7 \%)$ \\
\hline Toxicities & & \\
\hline Hematological & 34 & $(40.4 \%)$ \\
\hline Nausea-vomiting & 19 & $(22.6 \%)$ \\
\hline Neurological & 10 & $(11.9 \%)$ \\
\hline
\end{tabular}

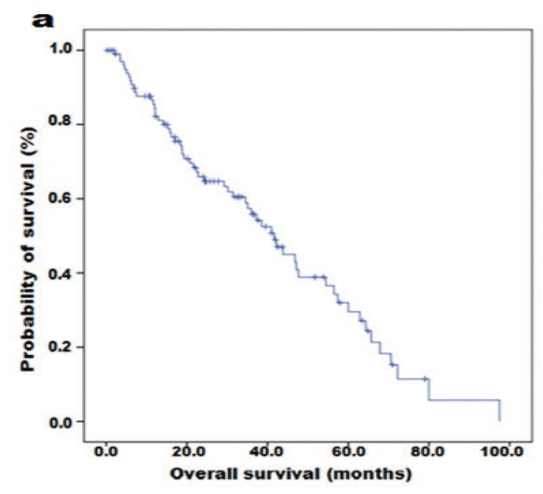

toxicities (40.4\%), nausea-vomiting (22.6\%) and neurological toxicities $(11.9 \%)$. Treatment results are given in Table 2.

The median survival for the overall patient population was 41.6 months (95\% CI=33.4-49.8) with a 5-year survival rate of $29.5 \%$ (Figure 1). In univariate analysis, stage, PS, adjuvant chemotherapy, and combination chemotherapy significantly affected OS. Patients that received adjuvant chemotherapy showed a significant longer OS (36.1 months vs. 56.4 months, $\mathrm{p}<0.01$ ) (Figure 1). Patients who received combination therapy showed better survival outcomes than the patients who received single-agent therapy (48.4 months vs. 42.7 months; $\mathrm{p}<0.05$ ). The median survival of the patients with stage 1 disease was longer than patients who had stage 2 disease (54.4 months vs 34.5 months, $\mathrm{p}<0.01)$. The median survival of the patients with a PS of 0-1 was longer than the patients with a PS of 2-4 (46.7 months vs 22.4 months, $\mathrm{p}<0.01)$. There were no relationships detected between weight loss, gender, smoking, histopathology, and OS $(\mathrm{p}>0.05)$. These data are shown in Table 3.

In multivariate analysis, PS, stage, and adjuvant chemotherapy showed a consistent relationship with OS and DFS $(\mathrm{p}<0.05)$ (Table 4). The median DFS was 22.6 months (95\% CI=16.728.4). Patients that received adjuvant chemotherapy showed a significantly longer DFS (24.1 months vs. 22.5 months, $\mathrm{p}<0.01)$. In univariate analysis, significant associations between stage, PS, adjuvant chemotherapy, and DFS were detected $(\mathrm{p}<0.05)$ (Table 3). In multivariate analysis, PS, stage, and adjuvant chemotherapy affected DFS (Table 4).

\section{Discussion}

Elderly patients represent a complex group based on their comorbidities and reduced functional reserves. Lung cancer is an important health issue in this population (12-15). To date, there has been no standard therapy accepted for NSCLC in the elderly; however JBR 10 trial and the meta-analysis of the Lung Adjuvant Cisplatin Evaluation and JBR 10 trials suggested that elderly patients benefited from treatment with acceptable toxicity $(13-15)$. It is predicted that there will be $67 \%$ more patients with lung cancer $\geq 65$ years by 2030 . Therefore, in this study we

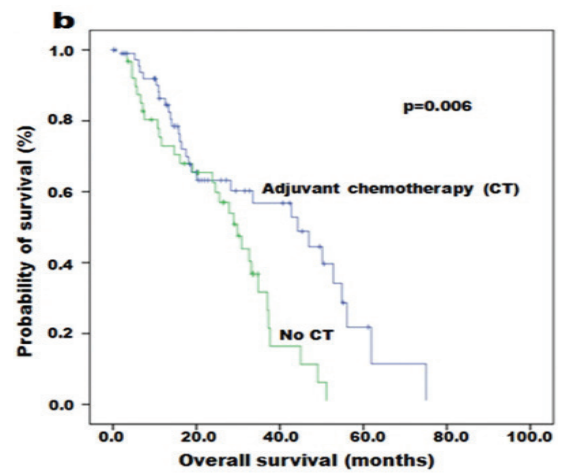

Figure 1. a) Median survival of the patients, b) Survival of the patients who did not receive adjuvant chemotherapy СТ: Chemotherapy 
Table 3. Univariate analysis between clinopathological characteristics of the patient group and OS and DFS

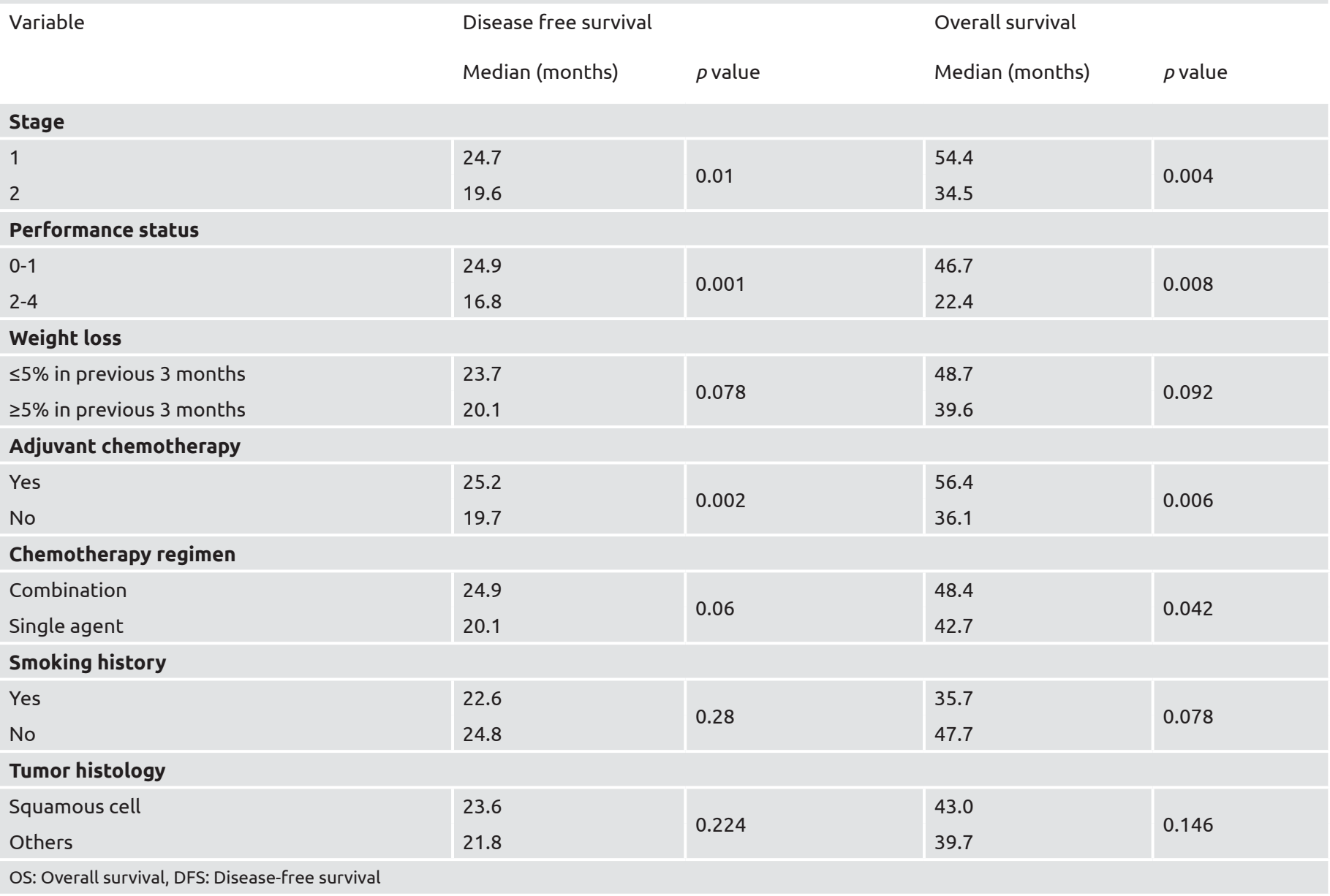

Table 4. The multivariate analysis between clinopathological characteristics of the patients and OS and DFS

\begin{tabular}{l|l|l|l|l|l|l|}
\multicolumn{4}{l}{} & \multicolumn{2}{l}{ Overall survival } \\
\hline Variables & Hazard ratio & $95 \% \mathrm{Cl}$ & $\mathrm{p}$-value & Hazard ratio & $95 \% \mathrm{Cl}$ & $\mathrm{p}$-value \\
\hline Performance status & 0.079 & $0.008-0.842$ & 0.033 & 0.074 & $0.008-0.830$ & 0.022 \\
\hline Adjuvant chemotherapy & 0.072 & $0.007-0.825$ & 0.024 & 0.078 & $0.007-0.826$ & 0.016 \\
\hline Stage & 0.080 & $0.009-0.840$ & 0.044 & 0.080 & $0.007-0.854$
\end{tabular}

OS: Overall survival, DFS: Disease-free survival

adressed our adjuvant treatment results in elderly patients with resected early-stage NSCLC.

The results of previous studies have demonstrated the benefit of chemotherapy in elderly patients with resected NSCLC (16). Früh et al. (15) showed that adjuvant cisplatin-based chemotherapy should not be withheld from elderly patients with NSCLC purely on the basis of age. Although our study included only small number of patients, our results were commensurate with the results of the aforementioned studies, all of which indicated that adjuvant chemotherapy and combination chemotherapy were well-tolerated and provided clinical benefits in elderly patients with early-stage NSCLC.

Patients treated with adjuvant chemotherapy had higher DFS and OS. Cisplatin- and carboplatin-based combination chemotherapy appeared to be tolerated well. In the database analysis conducted by Cuffe et al. (13), 3759 patients $\geq 65$ years receiving adjuvant chemotherapy showed better OS. Although JBR 10 confirmed a survival benefit for cisplatinvinorelbine in patients $\geq 65$ years, we found a trend towards using carboplatin-based combinations (14). These findings are consistent with those of a new study conducted in 2789 patients with resected NSCLC (16). When platinum chemotherapies were compared, superiority with respect to toxicities and efficacy were not detected. Similar findings were detected in two recent population-based analyses $(13,17)$. Collectively, these results indicate that patients $\geq 65$ years with resected early-stage NSCLC benefit from adjuvant chemotherapy.

Approximately $25-30 \%$ of all NSCLC cases are diagnosed at an early stage (18). With the increasing usage of computed 
tomography, the incidence of early cancers is expected to increase (19). Surgical removal at this early stage represents the maximal opportunity for long term survival in lung cancer (20). Fiveyear relative survival rates for localized lung cancer were 54\% and $26.5 \%$ for regional lung cancer (21). Five-year survival after lobectomy for stage 1 NSCLC was found to range from $45 \%$ to $65 \%$, depending on the stage and the location of the cancer (22). Demirci et al. (23) evaluated 26 patients with NSCLC who were older than 70 years and underwent surgery and received adjuvant treatment. The median OS was 21.8 months for stage $1 \mathrm{~B}, 35.4$ months for stage $2 \mathrm{~A}, 27.6$ months for stage $2 \mathrm{~B}$ and 21.8 months for stage $3 \mathrm{~A}$ disease (23). In our study, the median survival for the total study population was 41.6 months with a 5 -year survival rate of $29.5 \%$. The median survival of the patients with stage 1 and 2 disease were 54.4 and 34.5 months with 5 -year survival rates of $45.9 \%$ and $27.1 \%$, respectively. Consistent with the aforementioned studies, our results confirmed the importance of stage.

Performance status is a predictor of OS in cancer patients, and is generally used to inform cancer treatment decisions $(24,25)$. Inal et al. (24) evaluated prognostic factors for OS in elderly ( $\geq 65$ years) patients with advanced NSCLC who received first-line cisplatin-based chemotherapy. They found PS as an important prognostic factor in elderly patients with advanced NSCLC (24). Also, the PS has already been considered as an important prognostic factor in elderly patients with advanced NSCLC in other studies $(25,26)$. Unal et al. (25) investigated the effect of various the prognostic factors on survival in NSCLC patients $\geq 65$ years. They found that PS in addition to stage and white blood cell and platelet count significantly influenced survival (25). In our study, we determined the importance of PS on survival in early-stage NSCLC for both DFS and OS.

Patients with comorbidity do not receive standard cancer treatments such as surgery, chemotherapy, and radiation therapy as often as patients without comorbidity, and their chance of completing a course of cancer treatment is lower (27). In our study, we observed that patients that were chosen for operation were carefully selected patients that had minimal comorbidities. This may cause bias for our results. Another limitation of our study was having limited number of patients especially compared with recently published studies (16). This may explain the relatively lower survival times compared with these studies.

Based on our study results, we recommend the usage of combination chemotherapy regimens in elderly patients with a good PS. It is important to note that the type of adjuvant chemotherapy used did not have an impact on survival. In conclusion, adjuvant chemotherapy should not be withheld based on age alone in patients with early-stage NSCLC.

\section{Ethics}

Ethics Committee Approval: Ethics committee approval was obtained from the local committee.

Informed Consent: Written informed consent was not obtained from patients due to the retrospective nature of the study.
Peer-review: Externally peer-reviewed.

\section{Authorship Contributions}

Concept: U.K., S.K., D.I., U.I., Design: U.K., S.K., K.U., Data Collection or Processing: S.K., D.I., A.S., Ö.A., Analysis or Interpretation: U.K., U.I., D.A., A.S., Ö.A., Ö.O., Literature Search: S.K., D.I., A.S., U.A., U.I., D.A., E.Ö., K.U. Writing: U.K.

Conflict of Interest: No conflict of interest was declared by the authors.

Financial Disclosure: The authors declared that this study received no financial support.

\section{References}

1. Siegel RL, Miller KD, Jemal A. Cancer Statistics, 2016. CA Cancer J Clin 2016;66:7-30.

2. T.CMinistry of Health. Turkey Cancer Statistics, 2016. Available from: http://kanser.gov.tr/ Dosya/ca_ istatistik/ANA_rapor_2013v01_2. pdf. Accessed: 22.05.2017.

3. Reade CA, Ganti AK. EGFR targeted therapy in non-small cell lung cancer: potential role of cetuximab. Biologics 2009;3:215-24.

4. Smith BD, Smith GL, Hurria A, Hortobagyi GN, Buchholz TA. Future of cancer incidence in the United States: Burdens upon an aging, changing nation. J Clin Oncol 2009;27:2758-65.

5. Pallis AG, Gridelli C, van Meerbeeck JP, Greillier L, Wedding U, Lacombe D, et al. EORTC Elderly Task Force and Lung Cancer Group and International Society for Geriatric Oncology (SIOG) experts' opinion for the treatment of non-small-cell lung cancer in an elderly population. Ann Oncol 2010;21:692-706.

6. Gridelli C, Shepherd FA. Chemotherapy for elderly patients with non-small cell lung cancer: A review of the evidence. Chest 2005; 128:947-57.

7. Balducci L. Geriatric oncology: challenges for the new century. Eur J Cancer 2000;36:1741-54.

8. Owonikoko TK, Ragin CC, Belani CP, Oton AB, Gooding WE, Taioli E, et al. Lung cancer in elderly patients: An analysis of the surveillance, epidemiology, and end results database. J Clin Oncol 2007;25:5570-77.

9. Oken MM, Creech RH, Tormey DC, Horton J, Davis TE, McFadden ET et al. Toxicity and response criteria of the Eastern Cooperative Oncology Group. Am J Clin Oncol 1982;5:649-55.

10. Therasse P, Arbuck SG, Eisenhauer EA, Wanders J, Kaplan RS, Rubinstein L, et al. New guidelines to evaluate the response to treatment in solid tumors. J Natl Cancer Inst 2000;92:205-16.

11. Miller AB, Hoogstraten B, Staquet M, Winkler A. Reporting results of cancer treatment. Cancer 1981;47:207-14.

12. Kefeli U, Kaya S, Ustaalioglu BO, Bilici A, Kefeli AU, Yildirim ME, et al. Prognostic factors in elderly patients with non-small cell lung cancer: a two-center experience. Med Oncol 2010;28:661-6.

13. Cuffe S, Booth CM, Peng Y, Darling GE, Li G, Kong W, et al. Adjuvant chemotherapy for non-small-cell lung cancer in the elderly: a population-based study in Ontario, Canada. J Clin Oncol 2012;30:1813-21. 
14. Pepe C, Hasan B, Winton TL, Seymour L, Graham B, Livingston $\mathrm{RB}$, et al. Adjuvant vinorelbine and cisplatin in elderly patients: National Cancer Institute of Canada and Intergroup Study JBR.10. J Clin Oncol 2007;25:1553-61.

15. Früh M, Rolland E, Pignon JP, Seymour L, Ding K, Tribodet H, et al. Pooled analysis of the effect of age on adjuvant cisplatin-based chemotherapy for completely resected non-small-cell lung cancer. J Clin Oncol 2008;26:3573-81.

16. Ganti AK, Williams CD, Gajra A, Kelley MJ. Effect of age on the efficacy of adjuvant chemotherapy for resected non-small cell lung cancer. Cancer 2015;121:2578-85.

17. Wisnivesky JP, Smith CB, Packer S, Strauss GM, Lurslurchachai L, Federman A, et al. Survival and risk of adverse events in older patients receiving postoperative adjuvant chemotherapy for resected stages IIIIIA lung cancer: observational cohort study. BMJ 2011;343:d4013.

18. American Cancer Society. Cancer Facts \& Figures 2016. Atlanta: American Cancer Society; 2016. Available from: https://www.cancer. org/content/dam/cancer-org/research/cancer-facts-and statistics/ annual-cancer-facts-and-figures/2016/cancer-facts-and-figures-2016. pdf. Accessed: 2.05.2017.

19. Patz EF Jr, Goodman PC, Bepler G. Screening for lung cancer. N Engl J Med 2000;343:1627-33.

20. Harpole DH Jr, Herndon JE II, Wolfe WG, Iglehart JD, Marks JR. A prognostic model of recurrence and death in stage I non-small cell lung cancer utilizing presentation, histopathology, and oncoprotein expression. Cancer Res 1995;55:51-6.

21. Howlader N, Noone AM, Krapcho M, Miller D, Bishop K, Altekruse SF, et al. SEER Cancer Statistics Review, 1975-2011, based on
November 2013 SEER data submission, posted to the SEER web site, April 2014. Bethesda, MD: National Cancer Institute; 2014. Available from: http://seer.cancer.gov/csr/1975_2011/ Accessed: 08.07.2015.

22. Ou SH, Zell JA, Ziogas A, Anton-Culver H. Prognostic factors for survival of stage I non small cell lung cancer patients: a population based analysis of 19,702 stage I patients in the California Cancer Registry from 1989 to 2003. Cancer 2007;110:1532-41.

23. Demirci NY, Ulger S, Yilmaz U, Aydogdu K, Yilmaz A, Erdogan Y. Radical Oncological Surgery and Adjuvan Therapy in Non- Small Cell Lung Cancer Patients over 70 years of Age. Asian Pac J Cancer Prev 2015;16:4711-14.

24. Inal A, Kaplan MA, Kucukoner M, Karakus A, Isikdogan A. Prognostic factors in elderly patients with advanced non-small cell lung cancer treated with first-line cisplatin-based chemotherapy: A retrospective analysis of single institution. J BUON 2012;17:533-6.

25. Unal D, Oguz A, Goksu SS, Tasdemir A, Kurtul N, Eroglu C, et al. Effect of prognostic factors on survival in elderly patients with nonsmall cell lung cancer. Turkish Journal of Geriatrics 2014;17:113-8.

26. Bunn PA Jr, Lilenbaum R. Chemotherapy for elderly patients with advanced non-small-cell lung cancer. J Natl Cancer Inst 2003;95:3413.

27. Søgaard M, Thomsen RW, Bossen KS, Sørensen HT, Nørgaard M. The impact of comorbidity on cancer survival: a review. Clin Epidemiol 2013;5:3-29. 